\title{
Chemical characterization of the essential oil of Thymus vulgaris and evaluation of its antifungal activity on the apple scab pathogen (Venturia inaequalis L)
}

\author{
Fouzia Benaliouche $^{1,2^{*}}$, Hana Sbartai ${ }^{2}$, Messaouda Meraghni ${ }^{1}$, Hakim Hadj-Moussa ${ }^{2}$, Ibtissem Sbartai ${ }^{2}$ \\ ${ }^{1}$ Regional Plant Protection Station, El Tarf, Algeria \\ ${ }^{2}$ Laboratory of cellular toxicology, Badji Mokhtar University, Annaba, Algeria
}

\begin{abstract}

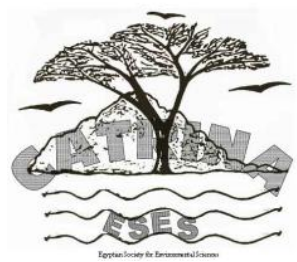

This study aims to investigate the chemical composition of essential oils (EO) extracted from the aerial part of Thymus vulgaris L. and to evaluate its antifungal activity against the apple scab pathogen (Venturia ineaqualis L). Chemical analysis of this EO revealed the presence of 30 compounds which represent for approximately $99.07 \%$ of the total component. Linalool, is the most abundant constituent $(36.41 \%)$, followed by Terpinen-4-ol $(10.51 \%)$ and $\beta$-myrcene $(7.5 \%)$. Other constituents were identified in varying amounts include para-Cymene (6.6\%); $\gamma$-Terpinene $(6.11 \%)$, and Carvacrol $(0.75 \%)$, with entirely absent of thymol compound. The evaluation of antifungal activity of thyme EO on the growth of Venturia ineaqualis mycelium was marked by a decrease in number of fungal filaments in the colony which was significantly influenced by increasing the doses. The EO concentration that had the minimal inhibitory effect was 3001/ml. Thymus vulgaris $\mathrm{EO}$ had a complete inhibitory effect on fungal growth at a dose of $600 \mathrm{l} / \mathrm{ml}$, where no growth was observed. Despite the absence of thymol and the relatively low content of carvacrol, both of which are known to be highly toxic, thyme EO from the Seraidi region was very effective and revealed a very powerful activity against V.ineaqualis, which is likely due to the presence of high levels of monoterpenes $(36.96 \%)$ and oxygenated monoterpenes $(55.51 \%)$ associated with other synergistic components.
\end{abstract}

Keywords: Antifungal activity, Chemical composition EO, CMI, Thymus vulgaris L., Venturia ineaqualis L.

\section{INTRODUCTION}

The world's production of apples amounted to 64 million tonnes in 2016, China is the largest producer of apples in the world, and the United States of America comes second, accounting for half of the global total (planetoscope). Algeria is ranked 26th in the world, with 503,303 tonnes produced over an area of 40,553 hectares. Its products may be found everywhere in the national territory (Haffaf and Merzougui, 2014). The area planted to apples in Algeria has risen significantly since the establishment of the National Agricultural Development Program (PNDA). Apple yields are still weak and irregular when compared to other countries with a smaller area under this crop. The apple is susceptible to a variety of parasites that must be controlled in order to prevent the spread of disease. Apple scab, caused by the pathogen of Venturia inaequalis has remarkable symptoms that obvious on leaves and fruits. This disease is the most economically destructive cryptogamic disease worldwide and Algeria in particular (Parisi et al., 2004).

The different production regions in Algeria represent climatic conditions favorable to the development of scab. Therefore, the sanitary state of the orchard, its topography, the sensitivity of the cultivars, and the frequency of the periods of infection, combined with the influence of other factors make this disease the primary source of economic losses in orchards that requiring frequent application. As a result, numerous phytosanitary treatments are required to achieve a suitable commercial quality. One of the major challenges in arboriculture is to reduce the number of phytosanitary treatments used in commercial orchards that leads to lowering both production costs and negative environmental and human health implications (Mills \& Laplante, 1951; Carisse et al., 2009).
Traditional chemical control is showing its limits and many arboriculturists are looking for new phytosanitary solutions. Consequently, the search for an alternative to chemical products through the use of natural substances is one of the solutions to limit the development of pathogens, among which are aromatic plant extracts and more specifically essential oils (PARISI et al., 2004).

Previous studies have already highlighted the effectiveness of using EOs as biopesticides and their microbial activity depends on the nature of its chemical compounds. The Mountain Savory essential oil, for example, which was studied as part of the Casdar HE project (2013-2016), shows a toxic effect on the apple scab pathogen (Mazoyer, 2016). This toxicity is linked to the main phenolic compounds (Carvacrol and thymol) present in this EO, each of which has a hydroxyl group that disrupts the integrity of the fungal plasma membrane (Ahmad et al., 2011). Similarly, Syzygium aromaticum and Eucalyptus citriodora EOs have been shown to be effective against apple scab with better efficacy than the commercial reference CuSO4 (Deweer et al., 2015; Muchembled et al., 2015) compared to Origanum compactum, Saturejamontana and thymus vulgaris EOs (thymol) which showed antifungal activity above the IC50 (Vital et al., 2018). However, thyme is known as an antimicrobial agent and its antifungal activity has been demonstrated by several authors. By El Ajjouri et al., (2008) on four lumber rot fungi, by Benhamou et al., 2012 on Aspergillus niger. Zahed et al., (2021) also demonstrated a larvicidal activity for this EO extracted from leaves harvested in the Mekhatria region (Ain Defla).

Researchs have confirmed the antimicrobial properties of a range of plants on several plant pathogens, but the number of studies currently available on the 
fungicidal activity of essential oils on the genus Venturia is limited compared to other fungal species. Therefore, our study aims to explore the chemical composition of essential oils (EO) that extracted from the aerial part of thyme (Thymus vulgaris L.) and to evaluate its antifungal activity on the apple scab pathogen (Venturia inaqualis L.)

\section{MATERIALS AND METHOD}

\section{Plant material}

The plant material chosen in the present study is Thyme which identified as Tymus vulgaris, belonging to family Lamiaceae, which is a subshrub native to the western Mediterranean region including Algeria. The identification of this herb was carried out at the laboratory of malherbology at the Regional Station of Plant Protection in El-Tarf.

The aerial part (leaves and stems) of thyme was collected in November 2017 in the region of Seraidi (North of Annaba). The leaves and stems were thoroughly washed to remove dust and then air dried in the shade place for about 15 days and then stored in paper bags in a dry place at a rate of $100 \mathrm{~g}$ per bag to be used for oil extraction.

\section{Fungal material}

The fungal pathogen (Venturia ineaqualis), which causes apple scab disease, was isolated from lesions developed on apple leaves collected from an orchard located in the commune of Ben M'hidi (El-Tarf). The identification of the fungal species, based on macroscopic observation (morphological aspect of mycelium, shape of ascospores formed, growth rate, mycelium colour) and the life cycle of fungal colony, was carried out.

\section{Extraction of the essential oil}

The extraction was carried out with a Clevenger type apparatus. Hydro-distillation consists of immersing $10 \mathrm{~g}$ of dried leaves in the shade in $100 \mathrm{ml}$ of distilled water for 2 hours. After obtaining the essential oil, the oil was decanted from the aqueous layer, dried with anhydrous sodium sulphate $\left(\mathrm{Na}_{2} \mathrm{SO}_{4}\right)$ and stored in sealed bottles at $4^{\circ} \mathrm{C}$ in a hermetically sealed bottle according to ISO 9235.

\section{Determination of Kinetic performance}

The recovered quantities of essential oil corresponding to 10 minute time intervals ranging from 0 to 90 minutes were measured to study the extraction kinetics of the essential oil from the dried aerial part of thyme. The yield, at each time interval, was calculated by the following formula (AFNOR, 1986):

$$
\text { RHE }(\%)=M^{\prime} / M \times 100
$$

Where, RHE is the yield of essential oil from the dry areal parts and $\mathrm{M}^{\prime}$ is the mass of essential oil $(\mathrm{g}), \mathrm{M}$ is the mass of dry plant material $(10 \mathrm{~g})$.

Chemical characterisation of the essential oil of Thymus vulgaris by Gas Chromathography (GC)

Chromatographic analysis

The chromatographic analysis was carried out at the
Centre de Recherche Scientifique et Technique en Analyses Physico-Chimiques (CRAPC-Centre for Scientific and Technical Research in Physical and Chemical Analysis), Algeria, on a Hewlett Packard electronically pressure regulated gas chromatograph (HP-5MS series), equipped with an HP-5 capillary column (30 m x $0.25 \mathrm{~mm}$ ) with a film thickness of $0.25 \mu \mathrm{m}$, an FID detector set at $200{ }^{\circ} \mathrm{C}$ and fed with a $\mathrm{H}_{2}$ /Air gas mixture and a split-split less injector set at $275^{\circ} \mathrm{C}$. The injection mode is split (leakage ratio: 1/50). The gas used is pure helium with a flow rate of $0.5 \mathrm{ml}^{-} \mathrm{min}^{-1}$. The column temperature is programmed from 50 to $250{ }^{\circ} \mathrm{C}$ at $4{ }^{\circ} \mathrm{C} \cdot \mathrm{Min}^{-1}$. The apparatus is controlled by a computer system of the HP Chem-Station type, which manages the operation of the apparatus and makes it possible to monitor the progress of chromatographic analyses (CRAPC, 2018).

\section{Evaluation of the antifungal activity of the essential oil of Thyme}

Isolation and identification of apple scab

Venturia ineaqualis was isolated from samples of young leaves showing symptoms of the disease. Samples of scabbed leaves were freshly cut with a scalpel, observed under a light microscope to confirm the presence of ascospores, then disinfected in $2 \%$ sodium hypochlorite for 10 minutes, followed by rinsing in 3 successive baths of sterile distilled water for 5 minutes each, and then dried between two sheets of sterile paper. The samples were then sliced into small pieces and plated on PDA medium. The plates were incubated at $18 \pm 2{ }^{\circ} \mathrm{C}$ for one week following the method of Ctifl, (2015).

\section{The reference fungicide used}

The score is the reference pesticide used in this experiment to compare its antifungal activity to that of thyme EO on the isolated fungal strain. It is a systemic fungicide, composed of $250 \mathrm{~g}$ of Difeno-conazole, used for the preventive and curative control of a wide spectrum of foliar diseases including apple scab. Score is rapidly diffused into the aerial parts of plants by translaminar action and local systemic action. It significantly blocks the development of mycelium in plant tissues and prevents the appearance of symptoms (Syngenta score data sheet, 2015).

Evaluation of antifungal activity of thyme essential oil on Venturia inaequalis

The antifungal activity of thyme essential oil was evaluated using the dilution technique in solid medium to determine the inhibition levels and in broth medium to determine the MIC and the MFC (Baba-Moussa, 1999; Batawila, 2002; Moulari, 2005).

\section{a. Solid-state dilution technique}

Each of the methanolic solutions $(0.5 \mathrm{ml})$ of the EO tested at different concentrations (100, 200, 300, 400, $500,600 \mu \mathrm{g} / \mathrm{ml}$ ) was added to $20 \mathrm{ml}$ of a warm Sabouraud medium at $40{ }^{\circ} \mathrm{C}$. After homogenisation, the mixture is poured into petri dishes. Inoculation was carried out by stabbing the medium and then the Petriplates were incubated for 7 days at $27{ }^{\circ} \mathrm{C}$. Mycelial 
growth was recorded daily. At the end, the diameters of the different colonies were measured to calculate the inhibition rate (I'\%) (Kordali et al., 2003).

$$
I^{\prime}(\%)=100 \times(d C-d E) / d C
$$

Where, $I^{\prime}(\%)$ is the inhibition rate expressed in percentage, $\mathrm{dC}$ is the diameter of colonies in the positive control' plates and $\mathrm{dE}$ is the diameter of colonies in the tested plates containing the essential oil. Each experiment was performed in triplicate with three separate trials for reliability of results. The efficacy of the EO on a given strain(s) can be assessed by expressing the proportion of those that showed an inhibition rate greater than or equal to $50 \%$.

\section{b. Liquid dilution technique}

This technique consists of two steps: the first step to determine the MICs and the second step to determine the minimum fungicidal concentration (MFC) following the method of Rotimi et al., (1988).

\section{Determination of MICs}

The various solutions that had inhibition percentages greater than $50 \%$ are retained. A volume of $100 \mu \mathrm{l}$ of these solutions is added to $900 \mu \mathrm{l}$ of liquid Sabouraud medium containing the strain to be tested. The tubes thus prepared are incubated at $27{ }^{\circ} \mathrm{C}$ for 7 days. After incubation, the tubes in which no mould growth is noted are identified; MIC is the minimum concentration for which no mould growth is noted. For the determination of the MFC, after having identified the tubes in which no growth of "spores" is recorded. The experiment is sustained where $950 \mu$ l of sterile liquid Sabouraud medium is introduced with $50 \mu 1$ of a determined test having presented a total inhibition. After 7 days of incubation, the subcultures in which there was no growth are noted; the MFCs are recorded.

\section{Statistical analysis}

The results are given as means \pm SD. The bioassay data were statistically processed by analysis of variance (ANOVA) and Tukey's test using Minitab 16.1.1 software. All experiments were done in triplicates.

\section{RESULTS AND DISCUSSION}

The essential oil of Thymus vulgaris has been used since ancient times to achieve many beneficial roles for human health. In this part of the study, we focused on evaluation the inhibitory potential of thyme oil, as antifungal for the pathogen caused apple scab disease. The chemical composition of the essential oil was also explored.

\section{Essential oil extraction kinetics and yield of essential oil}

Extraction kinetics consists of determining the yield as a function of extraction time. The study revealed that the time needed to extract the maximum amount of oil is in a direct proportion with time of extraction. The extraction kinetics of the essential oil from the dry leaves of Thymus vulgaris (figure 1), indicates that the yield rapidly increased as a time function and then stabilised towards a plateau equivalent to $80 \mathrm{~min}$.

The yield of $T$. vulgaris essential oils from the Seraidi region provided a rate of about $1.58 \%$. These results are similar to the work of Djeddi et al., (2015) on the same studied species (Thymus vulgaris) collected in the same region with a yield equal to $1.55 \%$.

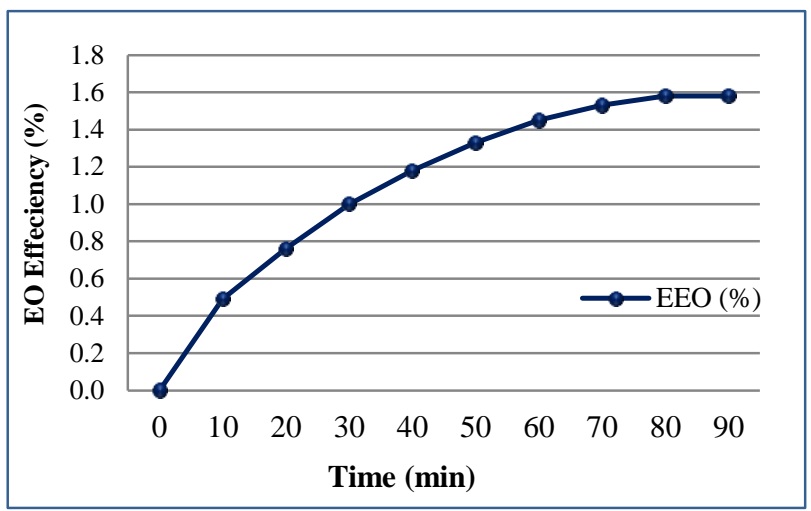

Figure (1): Extraction kinetics of thyme essential oil (EEO).

Additionally, the results of Bouguerra et al., (2017) on $T$. vulgaris collected in the region of Blida located in the north are relatively close to the thyme from the eastern region: Souk Ahras with a yield of $2 \%$. In parallel, the results obtained by Yakhlef (2010) indicated that the dry leaves of thyme from the Batna region (eastern Algeria) yielded essential oil contents equivalent to $1.94 \%$. In contrast, this rate is far from that found in thyme oil grown in the region of Tlemcen (North-West) which recorded a higher yield of around 4.2\% (Abdelli et al., 2017). The difference in results could be referred to many factors including the geographical distribution of the plant species, the phenological stage, storage, and the mode of extraction.

\section{The main compounds of the essential oil detected by Gas Chromatography}

Chemical analysis of the essential oil using Gas Chromatography (GC) detected 30 compounds which represent about $99.07 \%$ (Table 1, Figure 2). The essential oil of $T$. vulgaris are composed by linaool $(36.41 \%)$ which presents the main major product, followed by Terpinen-4-ol (10.51\%), $\beta$-Myrcene (7.5), respectively. Other constituents are identified at relatively medium levels which include: para-Cymene (6.6\%) $\gamma$-terpinene $(6.11 \%), \alpha$-thujene $(4.28 \%)$, borneol (4.18\%), Tricy-clene (3.31), $\beta$-pinene $(2.48 \%)$, Limonene (2.45) $\alpha$-Terpineol (2.05\%) eucalyptol (1.72), $\beta$-caryophyllene $(3.57 \%), \alpha$-Terpinene $(3.1 \%)$ and $\beta$-pinene $(2.48 \%)$. On the other hand, the chemical analysis also revealed a rather low content of carvacrol $(0.75 \%)$ and the total absence of thymol.

It is known that the genus Thymus comprises more than 300 species, 11 of which are located in Algeria 
(Kaabouche, 2005). Within each species there is variability in its chemical profile which is due to the chemotype, which has made it possible to distinguish differrent essential oils of varying composition from the same species. Thymus vulgaris is the model with most marked by this diversity in essence. Several chemotypes have been characterised, based on the nature of the majority monoterpene including linalool; borneol; geraniol; sabinene hydrate; thymol; carvacrol, (Thompson et al., 2003, Satyal et al., 2016).

Several previous studies have recognised the quantitative and qualitative variability in the chemical composition of Thymus vulgaris from different regions in Algeria, such as Bougerra et al., (2017), who determined a yield of $1.58 \%$ for thyme EO with an identical chemo-type as those identified in our study, which is characterised by a very high linalool content that exceeds 80 percent in the region of Tebessa (East of Algeria). In contrast, according to Stahl-Biskup and Sàez (2002), the chymo-type of Chlef is characterised by thymol as the primary product and low linalool levels $(1.66 \%)$.

Additionally, a study done by Benhamou et al., (2012) concluded that the drying technique has a strong influence on the content of the major compound detected, while other investigation done by Svoboda and Hampson (1999) pointed out that the extraction procedures are a determining factor for the number of chemical compounds in EOs. Indeed, various factors, including edaphic, climatic, environmental, and genetic factors, are thought to have a role in thyme polymorphism (Bougerra et al., 2017).

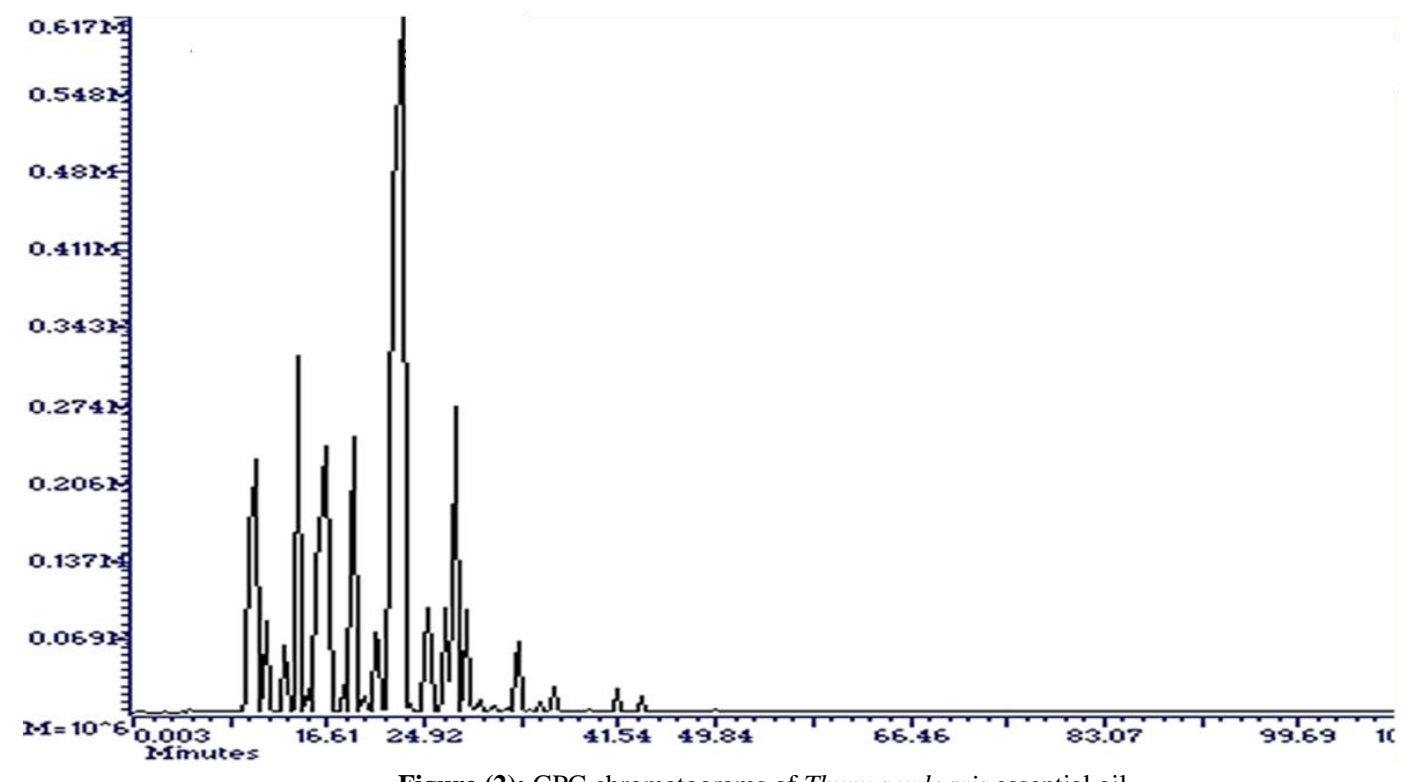

Figure (2): GPC chromatograms of Thymus vulgaris essential oil

\section{Antifungal effect of Thyme essential oil on Venturia ineaqualis}

Table 2 summarizes the results the antifungal effect of thyme EO on apple scab in which an inhibitory effect, of the applied doses on the growth of Venturia ineaqualis, was observed after 7 days of incubation wherea marked decrease in the colony diameter of the fungal colony. This decrease was calculated by light microscopy as a function of increasing EO concentrations and associated with a deformation of the filament structure. The $400 \mu \mathrm{l} / \mathrm{ml}$ and $500 \mu \mathrm{l} / \mathrm{ml}$ doses recorded a strong activity on the density of the scab mycelium which is manifested by a reduction in the number of filaments, 18 and 12 filaments respectively, compared to the control value (289.33 filaments). Finally, the $600 \mu 1 / \mathrm{ml}$ dose completely inhibited scab mycelial growth proving that this oil has the same antifungal activity compared to reference control.

Table 2-3, also showed that all doses injected, ranging from $100 \mu 1 / \mathrm{ml}$ to $600 \mu 1 / \mathrm{ml}$, in the culture medium exerted a highly significant inhibitory effect $(p \leq 0.001)$ on the tested strain. The doses of $100 \mu 1 / \mathrm{ml}$ and $200 \mu \mathrm{l} / \mathrm{ml}$ showed a fairly close effect $(36 \%$ and $67 \%$ ) based on Tuckey test. In meantime, the doses of $300 \mu \mathrm{l} / \mathrm{ml}$ and $400 \mu \mathrm{l} / \mathrm{ml}$ exhibited the inhibitory activity with a higher rate of $77 \%$. Meanwhile, the highest dose of $600 \mu \mathrm{l} / \mathrm{ml}$ proved to be the most active dose towards the Venturia ineaqualisstrain where it pronounced a fungicidal effect similar to that of the reference fungicide. This dose showed a complete inhibition of fungal growth during the time period of incubation (Figure 3).

Evaluation of MIC and MFC on liquid showed that the $300 \mu 1 / \mathrm{ml}$ dose recorded the minimum inhibitory concentration (MIC) and the highest dose $600 \mu 1 / \mathrm{ml}$ is the fungicidal dose where no growth was detected (MFC, Table 3). These results are consistent with those obtained on incorporated media where the $600 \mu l$ dose proved to be the most toxic to the phytopathogenic fungus. 
Table (1): The main compounds of the Thymus vulgaris essential oil detected by GPC at different retention time (RT).

\begin{tabular}{|c|c|c|c|c|c|}
\hline $\begin{array}{l}\text { No of compound } \\
\text { recorded }\end{array}$ & Compounds detected & RT & $\begin{array}{c}\text { Kovats } \\
\text { retention } \\
\text { index } \\
(\mathrm{KI}) \\
\end{array}$ & Area \% & $\begin{array}{l}\text { Class of compounds } \\
\text { detected }^{*}\end{array}$ \\
\hline 1 & Tricyclene & 10.18 & 926 & 3,31 & Bicyclic monoterpenoids \\
\hline 2 & $\alpha$-thujene & 10.59 & 933 & 4,28 & Bicyclic monoterpenoids \\
\hline 3 & Camphene & 11.44 & 947 & 1,34 & Bicyclic monoterpenoids \\
\hline 4 & Sabinene & 12.99 & 972 & 1,02 & Bicyclic monoterpenoids \\
\hline 5 & $\beta$-Pinene & 13.17 & 975 & 0,48 & Bicyclic monoterpenoids \\
\hline 6 & $\beta$-Myrcene & 14.25 & 992 & 7,5 & Acyclic monoterpenoids \\
\hline 7 & $\alpha$-Phellandrene & 15 & 1004 & 0.28 & Menthane monoterpenoids \\
\hline 8 & $\alpha$-Terpinene & 15.88 & 1016 & 3.1 & Menthane monoterpenes \\
\hline 9 & para-Cymene & 16.5 & 1025 & 6.6 & Aromatic monoterpenoids \\
\hline 10 & Limonene & 16.76 & 1028 & 2.45 & Menthane monoterpenoids \\
\hline 11 & Eucalyptol & 16.92 & 1031 & 1.72 & Oxanes \\
\hline 12 & (E)- $\beta$-Ocimene & 18.14 & 1048 & 0.33 & Acyclic monoterpenoids \\
\hline 13 & $\gamma$-Terpinene & 18.92 & 1059 & 6.11 & Menthane monoterpenoids \\
\hline 14 & cis-Sabinene hydrate & 19.58 & 1068 & 0.22 & Bicyclic monoterpenoids \\
\hline 15 & cis-linalool oxide & 19.92 & 1073 & 0.29 & Tetrahydrofurans \\
\hline 16 & Terpinolene & 20.93 & 1087 & 1.26 & Menthane monoterpenoids \\
\hline 17 & Linalool & 23.14 & 1117 & 36.41 & Acyclic monoterpenoids \\
\hline 18 & 1-Octen-3-yl acetate & 23.31 & 1120 & 0.1 & Carboxylic acid esters \\
\hline 19 & Camphor & 25.19 & 1146 & 1.99 & Terpenoid ketones \\
\hline 20 & Hexyl isobutanoate & 25.55 & 1151 & 0.68 & Carboxylic acid esters \\
\hline 21 & Borneol & 26.78 & 1168 & 4.18 & Bicyclic monoterpenoids \\
\hline 22 & Terpinen-4-ol & 27.74 & 1181 & 10.51 & Menthane monoterpenoids \\
\hline 23 & $\alpha-$ Terpineol & 28.54 & 1192 & 2.05 & Sesquiterpenoids \\
\hline 24 & (2E)-Hexenyl butanoate & 28.73 & 1195 & 0.1 & Fatty acid esters \\
\hline 25 & Verbenone & 29.7 & 1210 & 0.16 & Bicyclic monoterpenoids \\
\hline 26 & Linalool acetate & 32.96 & 1265 & 1.29 & Acyclic monoterpenoids. \\
\hline 27 & Bornylacetate & 34.87 & 1297 & 0.1 & Bicyclic monoterpenoids \\
\hline 28 & Carvacrol & 36 & 1312 & 0.74 & Aromatic monoterpenoids \\
\hline 29 & Geranyl acetate & 41.43 & 1381 & 0.26 & Acyclic monoterpenoids \\
\hline Total & (E)-Caryophyllene & 43.5 & 1414 & 0.21 & $\begin{array}{l}\text { Bicyclic sesquiterpene } \\
99.07 \%\end{array}$ \\
\hline
\end{tabular}

${ }^{*}$ Class of compounds detected and their percentage, Monoterpenes, 36.96\%; Oxygenated monoterpenes, $55.51 \%$; Sesquiterpenes, $0.21 \%$; Other compounds, $6.39 \%$.

Genus Thymus has a diverse range of therapeutic properties, the most notable of which is antimicrobial activity (Ourani et al., 2007; Yang and Clausen, 2007). This could be promising in the development of new biological pesticides, since recent studies have revealed that plant protection products have paradoxical effects.

In the present study, an antifungal activity was detected for all applied doses against the mycelial proliferation of Venturia ineaqualis where we observed a decrease in the number of filaments constituting the fungal colonies leading to an inhibition of the radial growth of the mycelium. This activity of thyme is probably linked to its chemical profile, in particular linalool, which exerted a remarkable action on the fungal strain tested. Linalool (3,7-dimethyl-1,6octadiene-3-ol) is a primary volatile monoterpene alcohol found in a significant number of essential oils of aromatic plants such as Lavandula angustifolia, Citrus bergamia, Ammi visnaga and Pistacia lentiscus (Letizia et al., 2003; Satraniet al., 2004; D'Auria et al., 2005; Isham et al., 2013; Beldi et al., 2020). Similar studies of Franchomme (1981) and Kurita and Koike (1982) discovered the properties of monoterpenols, the major products of the oils studied. This is confirmed by the 
Chemical characterisation of the essential oil

Table (2): Effect of Thymus vulgaris essential oil on filament number and radial growth (RG) of Venturia ineaqualis

\begin{tabular}{|c|c|c|c|c|c|c|c|c|}
\hline \multirow{2}{*}{ Treatments } & \multicolumn{7}{|c|}{ Incubation days } & \multirow{2}{*}{ RG $(\%)$} \\
\hline & 1 & 2 & 3 & 4 & 5 & 6 & 7 & \\
\hline Control (-) & $95.67 \pm 4.51^{\mathrm{a}}$ & $181.67 \pm 3.06^{\mathrm{a}}$ & $300 \pm 2.65^{\mathrm{a}}$ & $408 \pm 3.00^{\mathrm{a}}$ & $411.33 \pm 3.06^{\mathrm{a}}$ & $301.33 \pm 4.16^{\mathrm{a}}$ & $289.3 \pm 3.51^{\mathrm{a}}$ & $100 \pm 0.00^{\mathrm{c}}$ \\
\hline Reference (+) & $0.0 \pm 0.00^{\mathrm{b}}$ & $0 \pm 0.00^{\mathrm{g}}$ & $0.0 \pm 0.00^{\mathrm{e}}$ & $0.0 \pm 0.00^{\mathrm{f}}$ & $0.0 \pm 0.00^{\mathrm{f}}$ & $0.0 \pm 0.00^{f}$ & $0.0 \pm 0.00^{f}$ & $100 \pm 0.00^{c}$ \\
\hline 100 & $0.0 \pm 0.00^{\mathrm{b}}$ & $0 \pm 0.00^{\mathrm{g}}$ & $0.0 \pm 0.00^{\mathrm{e}}$ & $0.0 \pm 0.00^{\mathrm{f}}$ & $0.0 \pm 0.00^{\mathrm{f}}$ & $0.0 \pm 0.00^{f}$ & $0.0 \pm 0.00^{f}$ & $100 \pm 0.00^{c}$ \\
\hline 200 & $0.0 \pm 0.00^{\mathrm{b}}$ & $62.36 \pm 2.52^{d}$ & $67.0 \pm 4.36^{\mathrm{c}}$ & $68 \pm 9.54^{c}$ & $52.3 \pm 3.21^{\mathrm{c}}$ & $76.3 \pm 2.08^{\mathrm{c}}$ & $52 \pm 2.65^{\mathrm{c}}$ & $67.0 \pm 8.00^{\mathrm{a}}$ \\
\hline 300 & $0.0 \pm 0.00^{\mathrm{b}}$ & $85.67 \pm 3.51^{\mathrm{c}}$ & $45.0 \pm 3.00^{\mathrm{d}}$ & $49.3 \pm 2.52^{\mathrm{d}}$ & $34.7 \pm 3.51^{\mathrm{d}}$ & $62.7 \pm 3.06^{\mathrm{d}}$ & $34.0 \pm 3.61^{\mathrm{c}}$ & $77.0 \pm 5.00^{\mathrm{ab}}$ \\
\hline 400 & $0.0 \pm 0.00^{\mathrm{b}}$ & $48.33 \pm 3.06^{\mathrm{e}}$ & $38.33 \pm 2.08^{\mathrm{d}}$ & $27.3 \pm 3.06^{\mathrm{e}}$ & $38.0 \pm 3.00^{\mathrm{d}}$ & $44.7 \pm 1.52^{\mathrm{e}}$ & $18.3 \pm 3.51^{\mathrm{d}}$ & $77.0 \pm 9.00^{\mathrm{ab}}$ \\
\hline 500 & $0.0 \pm 0.00^{\mathrm{b}}$ & $29.64 \pm 3.06^{\mathrm{f}}$ & $23.0 \pm 0.00^{\mathrm{e}}$ & $18.0 \pm 2.65^{\mathrm{e}}$ & $17.0 \pm 1.52^{\mathrm{e}}$ & $15.0 \pm 3.00^{\mathrm{f}}$ & $12.0 \pm 4.58^{\mathrm{f}}$ & $88.0 \pm 5.00^{\mathrm{b}}$ \\
\hline 600 & $0.0 \pm 0.00^{\mathrm{b}}$ & $0.0 \pm 0.00^{\mathrm{g}}$ & $0.0 \pm 0.00^{\mathrm{f}}$ & $0.0 \pm 0.00^{\mathrm{f}}$ & $0.0 \pm 0.00^{\mathrm{f}}$ & $0.0 \pm 0.00^{\mathrm{f}}$ & $0.0 \pm 0.00^{\mathrm{f}}$ & $100 \pm 0.00^{\mathrm{c}}$ \\
\hline
\end{tabular}

Table (3): MIC and MFC of Thymus vulgaris EO on the apple scab pathogen (Venturia inaeqaulis)

\begin{tabular}{lcccccc}
\hline \hline EO doses $(\mu \mathrm{l} / \mathrm{ml})$ & 100 & 200 & 300 & 400 & 500 & 600 \\
Venturia ineaqualis & + & + & MIC & - & - & MFC \\
\hline \hline
\end{tabular}




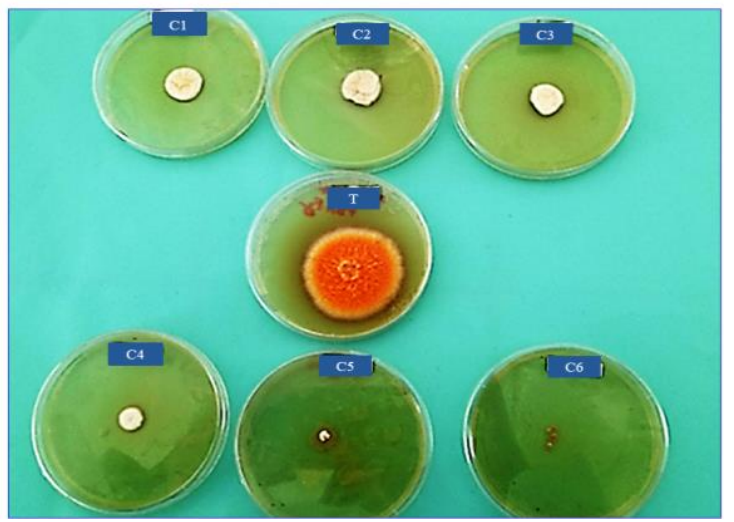

Figure (3): Antifungal Activity test showing the effect of different concentration of essential oil of Thymus vulgaris on the radial growth of apple scab. $\mathrm{T}=$ control; $\mathrm{C} 1=100, \mathrm{C} 2=200, \mathrm{C} 3=300, \mathrm{C} 4=400, \mathrm{C} 5=500$, C6 $=600 \mu \mathrm{g} / \mathrm{ml}$.

work of Hitokoto et al., (1980) and Prabodh et al., (2016) who demonstrated the ability of coriander oil to inhibit the growth of several strains of Aspergillus due to its high linalool content. In another study, Isham et al., (2013) illustrated that linalool has an antifungal effect on Candida albicans by inhibiting the formation of germ tubes and biofilm, both of which are involved in the infection process of apple scab. In confirmation to that study Hochbaum et al., (2018) reported antigerminative activity of thyme (Thymol chemotype) against apple scab.

In an attempted to clarify the mechanism of antifungal activity by linalool, Khan et al., (2010) and Zore et al., (2011) proved that linalool disrupts ergosterol biosynthesis by acting on membrane integrity and may also block the target strain's cell cycle. In the current study, the fungicidal activity was detected at dose of $600 \mu \mathrm{l} / \mathrm{ml}$ of Thymus vulgaris EO, where no growth was observed. This finding is promising as a large-scale manufacturing tool.

The activity of EO is often explained by the presence of the major products whereas it is preferable to emphasise the effect of the minority products, which may be effective by acting synergistically. According to the study done by Lahlou (2004), the use of the "totum" is more effective against the pathogen than the action of its major product. In addition, La Torre et al., (2016) recorded the applying of Thymus vulgaris EO against Fusarium oxysporum and $F$. splycopersici produced better results than the main product thymol. Furthermore, other constituents of thyme could contribute to this activity such as Terpènol-4-ol present in a significant percentage. Alama et al., (2017) found that Malaleuca alternifolia exhibited an inhibitory potential against Candida albicans probably due to Terpinol-4-ol.

Despite the absence of thymol and the rather low carvacrol content of $0.74 \%$, thyme EO from the Seraidi region was very effective and revealed a very powerful activity against Venturia ineaqualis. Some authors have attributed the antimicrobial power of EO to the presence of oxygenated monterpenes in high levels (Marzoug et al., 2011). This result corroborates with our results where the percentage exceeds $55 \%$. These oxygenated compounds can cause alterations in the walls of the target strains due to their high solubilisation (Griffin et al., 1999; Hammer et al., 2003).

\section{CONCLUSION}

This study highlighted the potential for using thyme essential oil (EO) to protect apple trees from the apple scab pathogen (Venturia ineaqualis). Evidently, the EO of Thymus vulgaris collected from Seraidi is characterized by high content of linalool and oxygenated monoterpenes, that giving it potent antifungal properties. However, the effectiveness of such molecules has been well demonstrated in the laboratory, it has yet to be proven in the field. To replace synthetic fungicides, it appears necessary to increase research efforts on this topic in order to propose EOs that retain their entire fungicidal efficacy on the field scale application to re-establish functional balances between the ecological compartments.

\section{REFERENCES}

ABDELLI, W., F. BAHRI, A. ROMANE, M. HÖFERL, J. WANNER, E. SCHMIDT, \& L. JIROVETZ. 2017. Chemical composition and antiinflammatory activity of Algerian Thymus vulgaris essential oil. Natural product communications 12(4).

AFNOR, 1986. Recueil des Normes Françaises huiles essentielles, AFNOR. Paris.p: 57.

AGHEL N., YAMINI Y., HADJIAKHOONDI A. \& MAHDI POURMORTASAVI S. 2004. Supercritical carbon dioxide extraction of Mentha pulegium L. essential oil. Talanta. 62,p: 407-411.

AHMAD, S., VEYRAT, N., GORDON-WEEKS, R., ZHANG, Y., MARTIN, J., SMART, L., \& TON, J. (2011). Benzoxazinoid metabolites regulate innate immunity against aphids and fungi in maize. Plant physiology, 157 (1), 317-327.

ALCAMO E. I. 1984. Fundamentals of Microbiology.. Addison-Wesly publishing company, London p:310-341; 617-699.

BABA-MOUSSA, F., K. AKPAGANA, \&P. BOUCHET. 1999. Antifungal activities of seven West African Combretaceae used in traditional medicine. Journal of ethnopharmacology, 66(3): 335-338.

BATAWILA, K. 2002. Diversité, écologie et propriétés antifongiques des Combretaceae du Togo. Acta Botanica Gallica, 149(4): 515-516.

BELDI, M., Boucheker, A., Djelloul, R., LAZLI, A. (2020). 'Physicochemical characterization and antibacterial and antifungal activities of Pistacia lentiscus oils in Northeastern Algeria., Catrina: The International Journal of Environmental Sciences, 22(1),pp.57-69.doi:10.21608/cat.-2021.45763.1061.

BENGTSSON, S. L., H.C LAU, \&R.E. PASSINGHAM. 2009. Motivation to do well enhances responses to errors and self-monitoring. Cerebral Cortex, 19(4) 797-804. 
BENHAMOU, A., I. ROUINA, \& F. FAZOUANE. 2012. Effect of solar drying on the chemical composition and antimicrobial activity of Thymus vulgaris essential oils.

BOUGUERRA, N., F. TINE-DJEBBAR, ANDN. SOLTANI. 2018. Effect of Thymus vulgaris L (Lamiales: Lamiaceae) essential oil on energy reserves and biomarkers in Culex pipiens L.(Diptera: Culicidae) from Tebessa (Algeria). Journal of Essential Oil Bearing Plants, 21(4): 1082-1095.

BOUGUERRA, N., DJEBBAR, F. T., \& SOLTANI, N. (2017). Algerian Thymus vulgaris essentialoil: Chemical composition and larvicidal activity against the mosquito Culex pipiens. Int. J. Mosq. Res, 4(1), 37-42.-42.

CARISSE, O., \& M. DEWDNEY.2002. A review of non-fungicidal approaches for the control of apple scab. Phytoprotection, 83(1): 1-29.

CARISSE, O., MELOCHE, C., BOIVIN, G., \& JOBIN, T. (2009). Action thresholds for summer fungicide sprays and sequential classification of apple scab incidence. Plant Disease, Vol. 93, No. 5, (May 2009) pp. 490-498, ISSN 0191-2917

D'AURIA, F. D., M. TECCA,V. Strippoli, G. Salvatore, L. Battinelli , and G. Mazzanti. 2005. Antifungal activity of Lavandula angustifolia essential oil against Candida albicans yeast and mycelial form. Medical mycology, 43(5): 391-396.

EL ALAMA, H., A. EL AISSAMI, A. BENMOUSSA, A.A.H. SAID, M. ARAHOU, AND F.E. EL ALAOUI-FARIS. 2017. Cinétique des interactions huile essentielle-antifongique Kinetics of the essential oil-antifungal interactions. Bulletin de la Société Royale des Sciences de Liège.

EL AJJOURI, M. \& SATRANI, BADR \& GHANMI, MOHAMED \& AAFI, ABDERRAHMAN \& FARAH, ABDELLAH \& MOHAMED, RAHOUTI \& AMARTI, F. \& ABERCHANE, MOHAMED. (2008). Antifungal activity of the thymus bleicherianus pomel and thymus capitatus (1.) hoffm. \& link essential oils against wood-decay fungi. 12. 129-135.

FRANCHOMME, P. 1981. L'aromatologie à visée anti-infectieuse. Phytomédecine, 1(2): 25-47.

GÉZA, N. A. G. Y., T. HOCHBAUM, S. SAROSI, AND M. LADANYI. 2014. In vitro and in planta activity of some essential oils against Venturia inaequalis (Cooke) G. Winter. Notulae Botanicae Horti Agrobotanici Cluj-Napoca, 42(1): 109-114.

HAFFAF, M AND MERZOUGHUI, H. 2014. Technical-cultural study of the Malus pumila Mill apple tree in the M'sila region, 60p

HAMMER, D., A. KAYSER, ANDC. KELLER. 2003. Phytoextraction of $\mathrm{Cd}$ and $\mathrm{Zn}$ with Salix viminalis in field trials. Soil use and management, 19(3): 187192.

HITOKOTO, H., S. MOROZUMI, T. WAUKE, S. SAKAI, H. AND KURATA. 1980. Inhibitory effects of spices on growth and toxin production of toxigenic fungi. Applied and Environmental Microbiology, 39(4): 818-822.
ISHAM, C. R., BOSSOU, A. R., NEGRON, V., FISHER, K. E., KUMAR, R., MARLOW, L., \& BIBLE, K. C. (2013). Pazopanib enhances paclitaxel-induced mitotic catastrophe in anaplastic thyroid cancer. Science translational medicine, 5(166), 166ra3-166ra3.

KABOUCHE, Z., N. BOUTAGHANE, S. LAGGOUNE, A. KABOUCHE, Z. AIT-KAKI, AND K. BENLABED. 2005. Comparative antibi-cterial activity of five Lamiaceae essential oils from Algeria. International Journal of Aromatherapy, 15(3): 129-133.

KHAN, A., A. AHMAD, F. AKHTAR, S. YOUSUF, I. XESS, L.A. KHAN, AND N. MANZOOR. 2010. Ocimum sanctum essential oil and its active principles exert their antifungal activity by disrupting ergosterol biosynthesis and membrane integrity. Research in microbiology, 161(10): 816823.

KORDALI, S., A. CAKIR, H. ZENGIN, AND M.E. DURU. 2003. Antifungal activities of the leaves of three Pistacia species grown in Turkey. Fitoterapia, 74(1-2): 164-167.

KURITA, N., AND S. KOIKE. 1982. Synergistic antimicrobial effect of acetic acid, sodium chloride and essential oil components. Agricultural and biological chemistry, 46(6): 1655-1660.

LA TORRE, A., F. CARADONIA, A. MATERE, AND V. BATTAGLIA. 2016. Using plant essential oils to control Fusarium wilt in tomato plants. European journal of plant pathology, 144(3): 487-496.

LAHLOU, M. 2004. Methods to study the phytochemistry and bioactivity of essential oils. Phytotherapy Research: An International Journal Devoted to Pharmacological and Toxicological Evaluation of Natural Product Derivatives, 18(6): 435-448.

LETIZIA, C. S., J. Cocchiara, J. Lalko, and A.M. Api. 2003. Fragrance material review on linalool. Food and Chemical Toxicology, 41(7): 943-964.

MARZOUG, H. N. B., M. ROMDHANE, A. LEBRIHI, F. MATHIEU, F. COUDERC, M. ABDERRABA,AND J. BOUAJILA. 2011 Eucalyptus oleosa essential oils: chemical composition and antimicrobial and antioxidant activities of the oils from different plant parts (stems, leaves, flowers and fruits). Molecules, 16(2): 1695-1709.

MAZOYER, A. Santé des plantes. ALTER AGRI JANVIER FEVRIER 2016. https://www.-planetoscope.com/fruits legumes/390-production-de-pommes-dans-le-monde.html.

MILLS, W.D., \& LAPLANTE, A.A. (1951). Diseases and insects in the orchard. Cornell Extension Bulletin, No. 711, 60 pages

MOULARI, B. (2005). Propriétés antimicrobiennes in vitro d'extraits de deux plantes africaines: rôle de l'astilbine: potentialisation du pouvoir antibactérien par nanoencapsulation (Doctoral dissertation, Besançon).

OURAÏNI, D., A. AGOUMI, M. ISMAILI-ALAOUI, K. ALAOUI, Y. CHERRAH, M.A. ALAOUI, M. AND M.A. BELABBAS. 2007. Activité antif- 
ongique de l'acide oléique et des huiles essentielles de Thymus saturejoides L. et de Mentha pulegium L., comparée aux antifongiques dans les dermatoses mycosiques. Phytothérapie, 5(1): 6-14.

PARISI L., F. DIDELOT, L. BRUN.2004. -Raisonner la luttecontre la tavelure du pommier: un enjeumajeur pour une arboriculture durable. Phytoma, 567:49-53.

SATRANI, B., A. FARAH, M. FECHTAL, M. TALBI, AND M.L. BOUAMRANI. 2004. Composition chimique et activité antibactérienne et antifongique de l'huile essentielle d'Ammi visnaga (L.) Lam. du Maroc. Acta botanica gallica, 151(1): 65-71.

SATYAL, P., B.L. MURRAY, R.L. MCFEETERS, AND W.N. SETZER. 2016. Essential oil characterization of Thymus vulgaris from various geographical locations. Foods, 5(4), 70.

STAHL-BISKUP, E. AND F. SÁEZ. (Eds.). 2002. Thyme: the genus Thymus. CRC Press.

SVOBODA, K.P. AND HAMPSON, J.B. 1999. Bioactivity of essential oils of selected temperate aromatic plants: antibacterial, antioxidant, antinflammatory and other related pharmacological activities. Ed: Plant Biology Department, SAC Auchincruive, Ayr, Scotland, UK., KA6 5HW.

THOMPSON, J. D., J.C. CHALCHAT, A. MICHET, Y.B. LINHART, AND B. EHLERS. 2003. Qualitative and quantitative variation in monoterpene co-occurrence and composition in the essential oil of Thymus vulgaris chemo-types. Journal of chemical ecology, 29(4): 859-880.

VITAL, R., J. MUCHEMBLED, C. DEWEER, L. TOURNANT, N. CORROYER, AND S. FLAMMIER. 2018. Évaluation de l'intérêt de l'utilisation d'huiles essentielles dans des stratégies de protecttion des cultures. Innovations Agronomiques, 63: 120.

YANG, V. W., AND C.A. CLAUSEN. 2007. Antifungal effect of essential oils on southern yellow pine. International biodeterioration \& biodegradation, 59(4): 302-306.

YU, J., R.J. GRIFFIN, D.R.COCKER III, R.C. FLAGAN, J.H. SEINFELD, AND P. BLANC-HARD. 1999. Observation of gaseous and partic-ulate products of monoterpene oxidation in forest atmospheres. Geophysical Research Letters, 26(8): $1145-1148$.

ZAHED, K., K. SOUTTOU, F. HAMZA, AND M. ZAMOUM. 2021. Chemical composition and larvicidal activities in vitro and in vivo of essential oils of Thymus vulgaris (L) and Lavandula angustifolia (Mill) against pine processionary moth Thaumetopoea pityocampa Den. \& Schiff. in Ain Defla (Algeria). Journal of Plant Diseases and Protection, 128(1): 121-137.

ZORE, G. B., A.D. THAKRE,S. JADHAV, ANDS.M. KARUPPAYIL. 2011. Terpenoids inhibit Candida albicans growth by affecting membrane integrity and arrest of cell cycle. Phytomedicine, 18(13): 1181-1190.

\section{التوصيف الكيميائي للزيت العطري المستخلص من نبات Thymus vulgaris وتقييم نثاطه المضاد للفطر المسبب لمرض جرب التفاح (Venturia inaequalis L)}

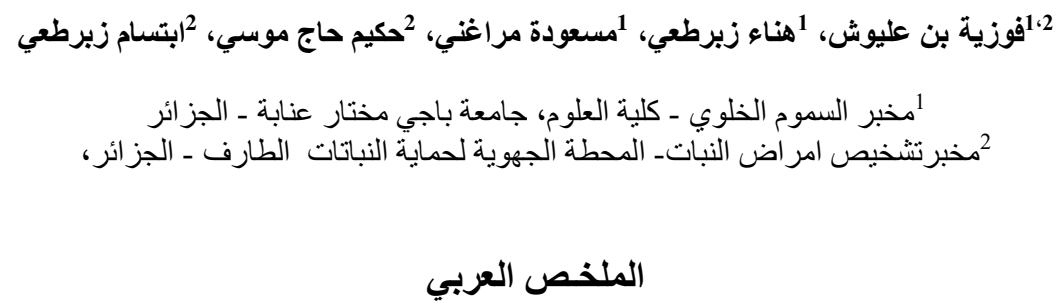

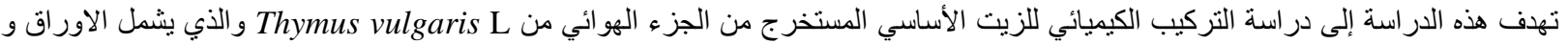

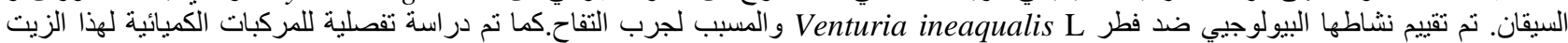

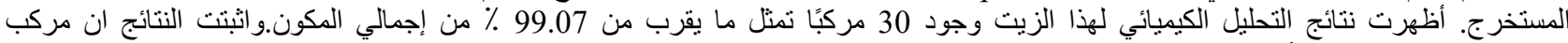

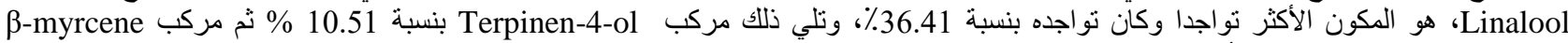

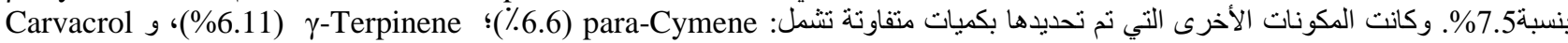

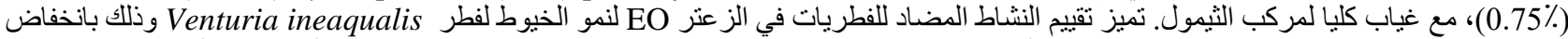

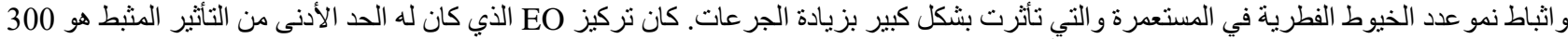

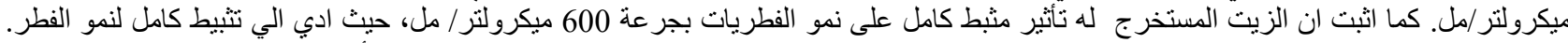

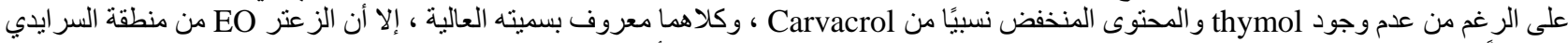

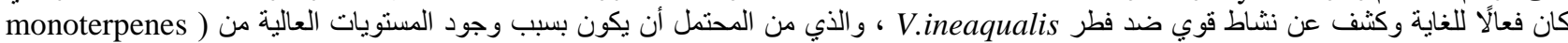

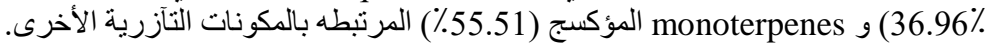

